\title{
The influence of socio - economic factors on crime
}

\author{
Grzegorz Pieszko, Ph.D ${ }^{1}$ \\ ${ }^{1}$ Wyższa Szkoła Społeczno - Gospodarcza z siedziba w Przeworsku, Poland
}

\begin{abstract}
Crime accompanies social life from its very beginning - it occurs in every society and in every stage of its development, regardless of its structure, system or historical period. Undoubtedly, crime is a consequence of many social and economic problems which constantly change, therefore there are so many controversial and unresolved issued connected with the influence of social and economical factors on crime. This article is an attempt to find an answer to whether the socio-economic factors clearly have a substantial impact on crime.
\end{abstract}

Keywords: law, economy, crime, society

\section{INTRODUCTION}

Crime accompanies social life from its very beginning - it occurs in every society and in every stage of its development, regardless of its structure, system or historical period [1]. Undoubtedly, crime is a consequence of many social and economic problems which constantly change [2]. Regardless of whether we like it or not - crime is a constant component of our life. The crime level is influenced by lots of factors which nature is heterogeneous. Among them, we may distinguish the socio - economic situation of the offender. Statistics (not only Polish) seem to confirm the assumption that there is a strong connection between social and economic conditions and the level of crime [3].Maria Szczepaniec in her article that focuses on law and economics claims that "the crime rate is essentially explained by studying how the changes in costs and profits from criminal activity influence the decision to commit a crime. According to the economic theory of crime an individual will be willing to commit an offense if the expected profit resulting from the criminal behavior will be higher than the profit resulting from the engagement in its legal alternative".

\section{SOCIO - ECONOMIC FACTORS}

Crime and changes in the structure of crime are both affected by such elements as: the degree of economic development, socio - political system that functions in a given country, the progress of industrialization and urbanization, transformations in social structure which are age-related to members of the society and finally, migrations. Transformations may be carried out in a revolutionary way or throughout a longer period of time, they can also occur suddenly as a result of some turbulent changeovers and rapid changes which happen in a given community. Poland during its over one thousand year long history experienced many breakthroughs, the consequence of which included, among other things, an increase or decrease in a crime rate in our country. Each time our land faced some switchover, including partitions or wars, or the period of recovery after the war, a period of restoration of independence - new conditions of society functioning were developed, which pervaded development of different social standards requiring protection by the authorities of the state [4]. The transformations taking place in the crime are naturally connected with common processes of social change, which applies to all societies. Political transformation of 1989 brought about changes in terms of intensification of crime, its type as well as the public perception of crime. As a result of the transformation, the analysis of the determinants of crime in contemporary Poland may be realized based on the same components for which the criminologists reach who describe the crime in postmodern societies: inequality and social exclusion, cultural changes that result from globalization, technological and information technology revolution [5] .

By analyzing the influence of socio - economic factors on crime in small communities - e.g. districts, one should take a closer look at the system of changes taking place globally in our country, as well as consider the system of changes which took place in post-communist country. Poland to such countries belongs. Thus, the dimension of social changes which took place, is much broader than in other countries of the Western Europe. In the case of our country one should consider political changes, accompanied by destabilizing and disintegrative processes, political changes with the transition from a communist to a democratic regime. Further modifications were related to the economic system, changes in ownership structure and the emergence of structural unemployment [6]. New conditions caused a shift in social structure, namely, new social groups were formed, social hierarchy was changed, and many social groups suffered economic degradation[7]. Furthermore, also cultural changes took place. On the one hand, there was an "inherited from the past" cultural system of rules (values and norms), formed under communism, with all the characteristic features of mental constellation described by some authors as "homo sovieticus" [8]. These include: support for egalitarianism, suspicion or 
"unfounded envy" of those who are doing better than we are, or an a demanding attitude [9]" On the other hand, a different culture is being shaped which "constitutes a functional requirement of new democratic and capitalist institutions [10]. he new system brings with it radically different cultural requirements based on the "republican virtues" and "civic culture" with the primacy of an individual as the supreme value, respecting the rights of human activity and willingness to participate in public life, which, in turn, requires certain amount of loyalty to authorities and trust in public institutions (the state/local authorities act as part of the system of law and under the law - causing the decisions they make are predictable for citizens and clear). Not all people are, of course, "culturally prepared" and able to act in this new "organizational context." Only a few have achieved, as Peter Sztompka emphasizes, the required by Western, capitalist and democratic civilization, "civilizational competence" [11].

The main problem that is being pointed to during discussions about the dependencies between the economic position and crime is an ambiguous result of analysis of the presented problem. There are data indicating that the weaker economic performance determine the decrease in crime, while other deny such relationship. However, there are studies which clearly confirm the intensification of crime as a symptom of a decline in the level of material situation. Probably the economic factors constitute an element which determines the development of crime, but not crime in its general understanding, but certain types of crime. Therefore, one should ask a question whether in fact the economic situation shapes the level of crime rate [12]. While being under constant modifications and transformations, society will never stay unchanged. Changes in the number, gender, age structure, migration (demographic changes) also have their mutual influence related to the economy, system of power, education, health protection, religion, and crime. Poor economic situation may translate into crime by an increase in unemployment. It should be noted that unemployment, naturally connected with the economy may have a different dimension. We distinguish between the structural, cyclical, long-term, and frictional unemployment[13]. Because of the social and demographic factors, such as gender, age or education level of people affected by the unemployment, there may be various relationships and impact on criminal activity.An analysis of police statistics shows that the highest intensity of crime occurs among unemployed people who are under thirty years of age [14]. If an individual is affected by long-term unemployment, he or she starts to be affected by the consequences of such a situation, namely a sense of exclusion, injustice, and finally the lack of hope of finding a legitimate source of income [15]. The analysis shows that unemployment brings on crime against property rather than violence [16]. However, it should be noted that the increase in unemployment in various ways may affect particular social groups by increasing or decreasing their criminal activity. At this point one should outline four specific relationships between unemployment and crime.

- Some offenders combine their legal professional work with criminal activity. Legal business is treated as a camouflage for illegal operation. In this case, the development of unemployment may reduce the "gray zone" business, as the legal work, in this case, gives a sense of security for conducting criminal activity.

- There is a number of crimes, possible to be committed only during conducting activities while being legally employed, for example: "handing over bribes to officials", "employee theft". In those situations the growth of unemployment will inhibit the number of crimes of the above mentioned type, rather than increase them.

- Young people, in particular distinguish between two options: being legally employed, or being involved in a criminal activity. If the lack of work prevails, the willingness to take an income from illegal sources may be decisive. Unemployment, in this perspective may cause an increase in crime.

- There are people for whom unemployment is strictly related to their living style. This group of people treat legal work as an abnormal situation - those people are not part of the labor market. For them, the lack of employment is part of their cultural identity, and criminal activity is, in their environment, a socially accepted source of income. In this case, an increase in unemployment will have no influence on the formation of criminal behavior. [17].

Further analysis of inter-relations of factors related to the discussed problem may incline to believe that in a period of an economic recession, a higher level of crime against property and lower against the person is being observed, whereas, during a period of prosperity (an economic boom) the situation is other way round: higher level of crime against the person and lower against property is being distinguished.

Apart from unemployment other economic factors such as: poverty, the level, dynamics and diversity of earnings and the pace of economic development influence the crime rate [18].

Poverty has long been the factor which has been strongly associated with criminal activity. As it was indicated by Alain Peyrefitte, "crime is the child of poverty"."[19]. Poles believe that there is a relationship between poverty and crime. For a part of our society the relationships between poverty and crime seem obvious, and if fact such relationships exist. However, it is worth to state that poverty is not a key determinant which really inclines people to commit an offense. Nonetheless people fear of the poor as a group. It is believed that poor people are dangerous and troublesome. The consequence of such believe cause that care and assistance 
for this group of people focus more on the control of this type of human population, rather than on providing them with indispensable support [20].

The increase in the gap between levels of wealth causes an increase in inequality between people. The bigger differences between the wealth level of social groups, the bigger possibility of social uneasiness and discontent. Inequality does not cause a growth in crime among the wealthy but has a higher impact on criminal behavior of those who have lower social stratus. The analysis of dependencies between social groups shows that if only a small percentage of people received very high income, and the majority of the population much lower, the vulnerability of the majority of those who earn less to commit a grime would be bigger [21].

Religion as a system of common beliefs and rituals may cause conflicts, integrate society, or initiate social changes or suppress them. In a varying degree it may also affect the functioning of society and its behavior. Published information and statistics concerning religious practice (dominicantes)) and the crime rate of 2010 point to certain regularities, namely, the fact that the crime rate is the lowest, where the level of religious practice (e.g attending church) is the highest. Most Catholics attend church in the following cities in Poland: Tarnów (70.5\%), Rzeszów (66.8\%) and Przemyśl (61.9\%). Consequently, Podkarpackie voivodeship in which the three aforementioned dioceses are located is the safest region in Poland. In this voivodeship such offenses as murder, theft, physical damage are caused least frequently (per 100,000 inhabitants)[22]. What is most interesting, the foresaid crimes are caused most frequently in the following voivodeships in Poland: Lubuskie, Zachodniopomorskie, Lódzkie and Warmińsko - mazurskie. The statistics of religious practices show cities in which the smallest percentage of people attend church, and these statistics clearly indicate szczecińsko kamieńska $(25,4 \%)$, koszalińsko - kołobrzeska $(27,1 \%)$ and lódzka $(27,3 \%)$ dioceses. Therefore, the connection between crime rate and religious beliefs exist, although there are people who claim that religion has no impact on human behavior. To prove this assumption, there are quoted statistics concerning the number of imprisoned and their attitude to faith. Statistics point to the fact that the percent of atheists who are imprisoned is lower than atheists who are present in the whole polish society.

While trying to explain the influence of socio - economic changes on crime, a number of changes in the economic system should be taken into account, such as the emergence of economic crises, periods of economic prosperity, the processes of European unification, EU enlargement, globalization, the processes of industrialization and urbanization. If the economic components affect almost all types of social activity, there must be a link between them and the crime. Conditions, economic tension may create some situations, often stressful situations that may facilitate criminal activity [23]. Initially, the analysis of the relationship between social and economic transformation and changes in the crime indicated that there is a causal connection, but now this assumption is not so obvious. One may only unquestionably talk about correlation between a group of various factors, also non-economical and certain types of crime.

A good economic situation, a period of prosperity may both influence either increase or decrease in the number of offenses. First of all, it may increase the possibility to commit a crime as the easiness and availability of products make them an easy target for a thief or even a person who has a desire to steal an item without really the need to have it. Abundance of goods cause that products may become an object of a crime (e.g become vandalized). Furthermore, if people have too much leisure, they tend to change their lifestyle - and this change is associated with taking part in or participate in events or actions with other people. This causes a greater opportunity for people to be involved in a prohibited actions and crimes against the person. A period of prosperity may, on the other hand decrease the possibility to commit a crime as people stick to generally accepted social standards and the desire to commit an illegal actions e.g. theft, swindle is reduced. They feel more socially secured and safe. The better social and economic status people have, the lower need to be involved in something prohibited by law. In case of a well-paid job, also motivational elements appear as well as the fear of the consequences of a wrongful act.

In literature of this field, there is no evidence that there is a connection between the level of crime and the level of industrialization. However, there is a strong connection between the level of crime and spatial mobility of the population, and the size of migration [24]. The internationalization of crime causes intensification of organized crime. Possibilities to commit a crime also change - smuggling, tax frauds, economic crime, production of drugs and weapon, money frauds, prostitution, „money laundering”, customs offenses, corruption.

The changing structure of crime, its forms and ways of committing it indicate a real change in social structure and transformations of the social life as well as missing norms and values of societies which in a given historical period may be observed.

\section{CONCLUSION}

The discussed and analyzed socio - economic factors incline to believe that social and economical sphere of human life is interrelated and interdependent. There are certain correlations with the crime level and social behavior as well as with economy and human vulnerability to commit an offense. However, careful 
examination in this respect is still needed. Causal dependencies which occur in societies on every stage of their development are difficult to explain. Yet the research, analysis of recovery plans and criminal statistics as well as literature allowed to form a conclusion that people should not only focus on individuals in crime prevention programs but on such forms of activity that would be targeted to whole societies. Preventive measures should aim at reducing both economic and social inequalities, e.g balance the level of incomeor promote social cohesion [25].

Although various crime preventive strategies and programs continue to be developed, they may only reduce crime rate on a small scale, basically they will not have a clear influence on the increase or decrease in a criminal activity in a particular country or in a global dimension as too many social and economic factors should be taken into account. Planned recovery activities should be focused on finding the causes that force people to commit crimes in a local or regional dimension and finding ways to improve a given situation or cause it bring other than criminal effects. Societies should learn from other societies and nations from other nations. Authorities should cooperate to find best way to weaken the desire or necessity of an individual to be involved in a criminal activity [26].

\section{REFERENCES}

[1] D. Woźniakowska - Fajst, Przestępczość dziś i jutro - stałość i zmienność struktury, [w] Społeczno polityczne konteksty współczesnej przestępczości w Polsce, Warszawa 2013, s. 11.

[2] Por. W. Klaus, I. Rzeplińska, D. Woźniakowska - Fajst, Spoleczny odbiór przestępczości, [w] Społeczno polityczne konteksty współczesnej przestępczości w Polsce, Warszawa 2013, s. 343.

[3] Por. M. Szczepaniec, Kontrowersje wokót wpływu warunków ekonomicznych na poziom przestępczości, [w] Czasopismo prawa karnego i nauk penalnych, z. 4, Kraków 2011, s. 107.

[4] K. Buczkowski, Stan przestępczości w Polsce od roku 1918 do wspótczesności, [w] Społeczno polityczne konteksty współczesnej przestępczości w Polsce, Warszawa 2013, s. 33 i n.

[5] A. Kossowska, Zmiana spoteczna a przestępczość - wzajemne zwiąki, uwarunkowania, konsekwencje, [w] Społeczno - polityczne konteksty współczesnej przestępczości w Polsce, Warszawa 2013, s. 73 i n.

[6] G. Pieszko, Spoteczeństwo polskie w okresie transformacji ustrojowo - gospodarczej, [w] Zeszyty Naukowe Uniwersytetu Rzeszowskiego nr 56, E. Dynia, W. Wlaźlak (red.), Rzeszów 2009, s. 187 i n.

[7] Por. G. Pieszko, Zjawisko fatszowania dokumentów na przykladzie regionu podkarpackiego $w$ latach 1990 - 2005. (Studium kryminologiczno - kryminalistyczne), Kraków 2012, s. 36,

[8] Patrz J. Tischner, Polski mlyn, Kraków 1991.

[9] M. Marody, Antynomie społecznej podświadomości, „Odra” nr 1, 1987, s. 4-9.

[10] P. Sztompka, Trauma wielkiej zmiany. Społeczne koszty transformacji, Warszawa 2000, s. 55.

[11] Tamże, s. 55, również tenże, Civilizational Incompetence: The Trap of Post-Communist Societies, „Zeitschrift für Soziologie”, No. 2, April 1993, s. 35-95.

[12] Por. M. Szczepaniec, op. cit., s.108.

[13] A. Kiersztyn, Czy bieda czyni złodzieja? Zwiazki między bezrobociem, ubóstwem a przestępczościa, Warszawa 2008, s. 37.

[14] T. Szymanowski, Polityka karna i penitencjarna w Polsce w okresie przemian prawa karnego, Warszawa 2005, s. 55.

[15] J. J. Sztaudynger, M. Sztaudynger, Ekonometryczne modele przestępczości, Ruch Prawniczy, Ekonomiczny i Socjologiczny 2003, nr 3, s. 129.M. Szczepaniec, op. cit., s. 110

[16] J. Błachut, A. Gaberle, K. Krajewski, Kryminologia, Gdańsk 2001, s. 248.

[17] J. J. Sztaudynger, M. Sztaudynger, op. cit., s. $128-129$.

[18] A. Peyrefitte, Wymiar Sprawiedliwości. Między ideałem a rzeczywistościa, Warszawa 1987, s. 246.

[19] W. Klaus, Relacje między bieda i wykluczeniem społecznym a przestępczościa, [w] Społeczno polityczne konteksty współczesnej przestępczości w Polsce, Warszawa 2013, s. 103 i n.

[20] J. J. Sztaudynger, M. Sztaudynger, op.cit., 133.G. Pieszko, Przestęstwa fatszowania dokumentów na tle przestępczości ogótem w województwie podkarpackim w latach 1999 - 2010, Studia Prawnoustrojowe 19, Olsztyn 2013, s. 152.

[21] J. Błachut, A. Gaberle, K. Krajewski, op. cit. s. 245.

[22] Ministerstwo Spraw Wewnętrznych i Administracji, Raport o stanie bezpieczeństwa w Polsce w 2010 roku, Warszawa 2011, s. 365.

[23] W. Klaus, Zapobieganie przestępczości - polityka społeczna przeciwdziałająca wykluczeniu społecznemu, [w] Społeczno - polityczne konteksty współczesnej przestępczości w Polsce, Warszawa 2013, s. 149 i n.

[24] W. Klaus, A. Kossowska, Skuteczność prowadzonych działań prewencyjnych, czyli co działa w praktyce, [w] Społeczno - polityczne konteksty współczesnej przestępczości w Polsce, Warszawa 2013, s. 195 i n. 